\title{
IRSYADUL MURID HISAB OF THE BEGINNING ISLAMIC LUNAR MONTH ON DIGITAL FALAK WEB-BASED
}

\author{
Iqnaul Umam Ashidiqi \\ UIN Walisongo Semarang \\ Jl. Walisongo No.3-5, Tambakaji, Kec. Ngaliyan, Kota Semarang, \\ Jawa Tengah 50185 e-mail: Iqnaumam72@gmail.com
}

\begin{abstract}
The development of astronomy in determining the beginning of the Islamic lunar month has occurred so rapidly, along with the sophistication of technology that makes it easy for users to get information. The digital falak web-based application was made by Ahmad TholhahMa'ruf an astronomy scholar from Islamic boarding school who presented the astronomy books. This web- based application displayed data and calculations in several books of astronomy inclusion including IrsyadulMuridbook. The research method used was qualitative with descriptive approach. The type of data used was library research. The results showed that the algorithm used in the early reckoning of Islamic lunar inIrsyadulMuridbook based on the digital falak web was different toIrsyadulMuridbook. The results of calculating the book IrsyadulMuridwith the digital falak web of celibacy were inappropriate which was done manually within the last 3 years making the results different. So, it could be concluded that the digital Falak web was inaccurate if it was used for rukyat data. Evaluation was necessarily needed, thus hisab(astronomical calculation) result in digital falak web-based would be equivalent to bisab in IrsyadulMuridbook.
\end{abstract}

Keywords:digital falak web,Islamic lunar month,IrsyadulMurid

\section{INTRODUCTION}

It is expected that as technology develops, science presentation advances. With the help of internet, current science is accessible through computer or mobile phone easily. According to Indonesia Internet Service Provider Association survey, more than half Indonesia population were connected to internet.

Tabel 1.1

Indonesia Internet Users Data in $2016^{1}$

\begin{tabular}{|l|l|c|c|}
\hline Year & Internet User & Presentage 100\% & Indonesia population \\
\hline 2014 & 88 million & $34,3 \%$ & \\
\hline 2016 & 132,7 million & $51,8 \%$ & 256,2 million \\
\hline
\end{tabular}

${ }^{1}$ Tekno.kompas.com/amp/read/2016/10/24/15064727/2016.pengguna.internet.di.indonesia.capai.132.jut a. Accessed on Thursday on February 9, 2017 at 13.00. 
Source:Tekno.kompas.com/amp/read/2016/10/24/15064727/2016.pengguna.internet.di.indonesia.capai .132.juta.

Based on the table above, the number of internet users had increased from $17,5 \%$ in 2016 to $34,3 \%$ in 2014. This increase was because people were connected to internet and could access everything from it. As the result of current development, falak(Islamic astronomy) experts were encouraged to create instrument in order to calculate Islamic lunar year. Previously, traditional Islamic lunar year calculation tools such as bilalocator, rubu' alMujayyaband istiwa' sticks were utilized. Afterwards, modern calculation tools were discovered in the form of web-based. There were numbers of application calculating the beginning month in the form of android, java and web. One of the web-based applications was digital falak web-based made by Ahmad TholhahMa'ruf. It presented prayer time, solaroccurrence time and hisab(astronomical calculation) program as well as calendar and was accessible for everyone.

\section{LITERATURE REVIEW}

KitriSulastri'sbachelor thesis on Study Analysis ofIrsyadulMuridBook onHisabof the Beginning Islamic Lunar Month concluded that theIrsyadulMuridhisabsystem and its method were contemporary way of $h i s a b^{2}$. Furthermore, it was scientifically proven in terms of accuracy level and could be reference in determining the beginning of lunar month. Based on Kitri's study, it could be concluded that IrsyadulMuridbook was modern and relevance as guidance in determining the beginning Islamic lunar month. Its accuracy level was higher than hisabtaqribi $^{3}$ or bisabhaqiqitahqiqit. However,

${ }^{2}$ Kitri Sulastri., Study Analysis of Irsyadul Murid Book on Hisab of the Beginning Islamic Lunar Month (Skripsi:S1 Fakultas Syari'ah IAIN Walisosngo Semarang,2011)h. 74 - 75.

${ }^{3} \mathrm{Hisab}$ Taqribi is hisabsystem utilizing astronomical and mathematic methods yet applies simple formula and data. Therefore, the hisab result would be inaccurate. Abd. Salam, Nawawi. Ilmu Falak : Cara Praktis Menghitung Waktu ShalatArah Kiblat dan Awal Bulan. (Sidoarjo : Aqaba, 2006) p. 5.

${ }^{4} \mathrm{Hisab}$ haqiqi tahqiqi is hisabsystem employing corrected tables,spherical geometry and more sophisticated formula than haqiqitakribihisab Sriyatin Shadiq, Perkembangan Hisab Rukyah
KitriSulastri's study differed to the researcher's discussion. The main research subject of this study was digital falak web-based made by Ahmad TholhahMa'ruf.

\section{RESEARCH PURPOSE}

There were two purposes of this study. The first purpose was exploring digital falak web-based hisab method used in determining the beginning of Islamic lunar month which was made by Ahmad TholhahMa'ruf. The second purpose was discovering the bisab accuracy level on determining the beginning Islamic lunar month. Therefore, the result of the study could be reference or guidance in determining the beginning Islamic lunar monthforfalak experts.

\section{RESEARCH METHOD}

This study employed qualitative research method $^{5}$ as well as descriptive ${ }^{6}$ evaluative $^{7}$ approach. It also referred as library research which analyzed literature sources such as books, encyclopedia, journals, magazines and other relevance sources ${ }^{8}$. Primary data source

dan Penetapan Awal Bulan Qomariyahdalam Menuju Kesatuan Hari Raya, (Surabaya : Bina Ilmu, 1995) p. 67.

${ }^{5}$ Qualitative research method is research method which is based on postpositive philosophy. It was intended to observe nature object which the researcher was as the key instrument. Qualitative research result highlights its significance instead of generalization. Sugiyono, Metode Penelitian Pendidikan Pendekatan Kuantitatif, Kualitatif danR \& D, (Bandung : Alfabeta, 2008) p. 207.

${ }^{6}$ Descriptive research is methodical, factual and accurate description of phenomenon or relationship among observable phenomena. Imam Suprayogo dan Tobroni, Metodologi Penelitian Sosial-Agama, (Bandung: PT Remaja Rosda Karya, 2001) p. 136 - 137.

${ }^{7}$ Evaluative approach is collecting policy implementation. Suharsimi Arikunto, Prosedur Penelitian: Suatu Pendekatan Praktik, (Jakarta: Rineka Cipta,2010) p. 37.

${ }^{8}$ Soerjono Sokanto dan Sri Mamudji, Penelitian Hukum Normatif SuatuTinjauan Singkat, (Jakarta: Rajawali, 1986) h. 15. 
consisted of primary and secondary data ${ }^{9}$. The primary data was in form of interview result towards Ahmad TholhahMa'ruf as the creator of digital falak web-based ${ }^{10}$. Then, the secondary datawas literature sources supporting the research.

\section{Ahmad TholhahMa'rufBiography}

Ahmad Tholhah bin Ma'ruf was born on June 13, 1981 in Pasuruan. He was the second of eight children ofMa'ruf and Maslihah. He lived in Masjid WarungdowoTimur, Warungdowo, Pohjentrek, Pasuruan Province, East Java and was married to FatimatuzZahro.He never attended formal education as other children did. At the age 9, he learned Islamic theology from 1994 to 2003.

In 1990 to 1992, he pursued his study in Al-Falah Islamic Boarding School, Lebak, Winongan, Pasuruan province for 2 years. Then he continued his study at Tahfizul Qur'an Education Boarding School at Sampuran 01 Bungah Stress, Gresik, East Java. In order to enrich his Islamic theology, hewent on to study at Al Falah Islamic Boarding School, Kediri in 1994 to 2003.

In the meantime, Ahmad Tholhah was interested in mathematics. He commenced to learn falak from his teacher, UstadzSulaiman from Surabaya. First, he learned how to operateCasio fx4300 calculator then Casio fx4500. He started to learn windows basic programming language in 2004 and commenced to master falak. Even though he spent his school time in non-formal education for 13 years, he was keen on technology and informatics. ${ }^{11}$

Several Ahmad TholhahMaruftreatises were digital falak android-based, digital falak web-based, VBA/VB6 tutorial on how to create hisab/falakby VBA (Visual Basic

\footnotetext{
${ }^{9}$ Jusuf Soewadji, Pengantar Metodologi Penelitian, (Jakarta: Mitra Wacana Media, 2012) h. 91.

${ }^{10}$ Imam Gunawan, Metode Penelitian Kualitatif Teori dan Praktek, (Jakarta : PT. Bumi Aksara, 2013) h. 162.

${ }^{11}$ Interview withBpk. Ahmad Tholhah bin Maeruf on Friday, 07 April 2017 at Masjid Warungdowo Timur, Warungdowo, Pohjentrek, Pasuruan Province, East Java at 09.00.
}

Application), Hisabby using ephemeris method papers,Falak papers on prayer time calculation and Qibla direction and falak terms glossary. In addition, there were many his works on other fields.

\section{Web-Based Application}

Web-based application was application or service which run inside server and could be accessed by utilizing web server everywhere through internet. Web-based application which was inside the website only could be accessed if the website was launched. In addition, website was a software coded in programming language, so it supported web-based software for instance HTML, JavaScript, CSS, Ruby, Python, PHP, Java and other programming languages.

A regular website was constructed on several connected webs. The connection between one to another website was identified as hyperlink while connector texts was called hypertext ${ }^{12}$. Initially, web was information space in the internet, by means of hypertext technology, which users were directed to seek information by following available link inside the web document. The web presented on web browser ${ }^{13}$.

Website was coined by Sir Timothy John, Tim Berners-Lee. In 2992, websites were connected to network. Then in 1993, Tim Berners-Lee and European Particle Physics Lab (ConseiEuropeenpor la RecercheNucleaire (CERN)) researchers in Geneva, Swiss ${ }^{14}$, developed one way to share data among their coworkers by using hypertext. CERN users

\footnotetext{
${ }^{12}$ Yuhefizer, S. Kom, dkk, Cara Mudah Membangun Website InteraktifMenggunakan Content Management System Joomla (CMS) Edisi Revisi, (Jakarta: PT. Elex Media Komputindo) p. 2. ${ }^{13}$ Betha Sidik dan Husni Iskandar Pohan, Pemrograman WEB denganHTML Revisi Kelima, (Bandung : Informatika, 2014) p. 1.

${ }^{14}$ M.Suyanto, Multimedia Alat Untuk Meningkatkan KeunggulanBersaing, (Yogyakarta : Andi, 2003) p. 45.
} 
could display document on screen by operating new browser software ${ }^{15}$.

At the same time in 1993, National Center for Supercomputer Applications (NCSA) launched a Graphical User Interface (FUI) which was called as Mosaic. Mosaic started to load picturewhich was equipped by audio or video link. As consequences, web became the most well-known media ${ }^{16}$. In 1994, Mosaic established Netscape Communication Corporation named Netscape Navigator. Then, it was followed by the advent of Microsoft Internet Explorer by Microsoft. On the contrary, in 1997, NSCA decided to withdraw the Mosaic development yet chose to work on other internet technology field ${ }^{17}$.

\section{Digital Falak Web-Based}

Digitalfalak was one of web-based applications created by Ahmad TholhahMa'ruf. It was created in 2015 after its android application launching and became first falak web-based application. It was found inside the web several interfaces which were fruitful to support falak needs for instances prayer time, hisab, and calendar.

\section{Picture 1.1: Digital Falak}

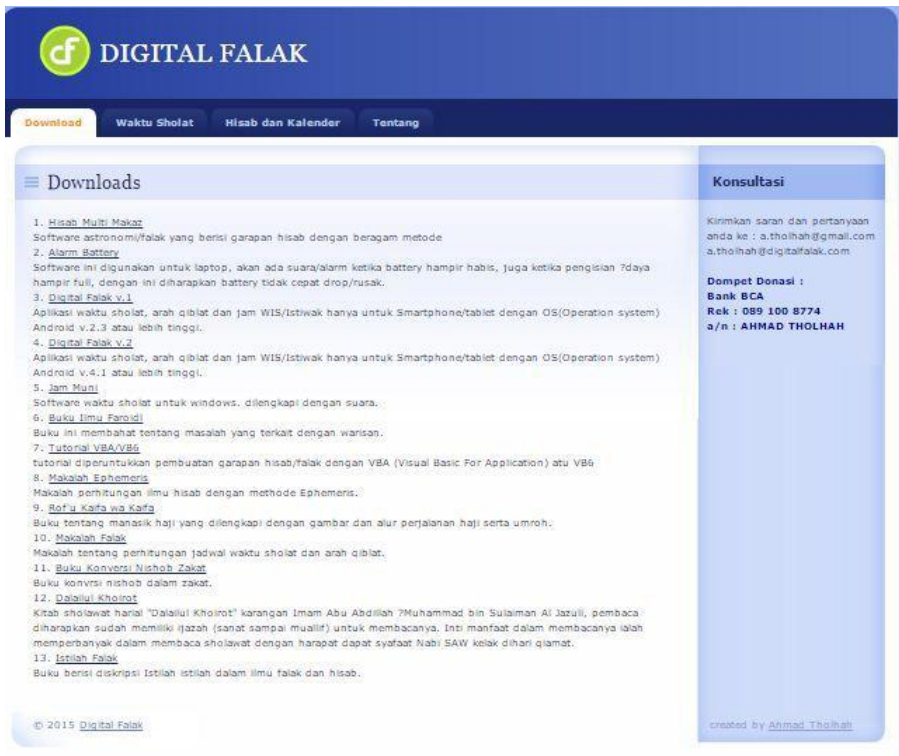

Source:https://www.digitalfalak.com/

The Algorithm Analysis of the Beginning Islamic Lunar Monthin Digital Falak WebBased Based on IrsyadulMuridBook

The Algorithm used for calculating the beginning Islamic lunar month in digital falak web-based was analogous with IrsyadulMurid's algorithm. As Ahmad ThohahMa'ruf used IrsyadulMuridhisab formula, he expected that the hisab result would be equivalent. Although he employed particular codes in order to add in PHP program language, the calculation reference was taken from IrsyadulMuridbook.

Nonetheless the researcher conducted the study on the algorithm of the beginning Islamic lunar month between digital falak webbased and IrsyadulMuridbook. The researcher discovered different formula used as the following;

1. The rationality of Common Era (C.E)month which was caused Ijtimia'(new month)

In IrsyadulMuridbook, the following is the formula used in order to attain C.E month which was Ijtima' caused Ijtima ${ }^{18}$

\footnotetext{
${ }^{18}$ Ijtima or iqtiran symbolizes "together or collection" which is the position month and sun are in the same astronomical longitude.Muhyidin Khazin, Kamus Ilmu Falak, (Jogjakarta: Buana Pustaka, 2005) p. 32
} 


\section{$\mathrm{BLN}=\mathrm{E}-1$}

If Eminus 1 would result C.E month which was caused Ijtima'. On the contrary, in PHP program code of IrsyadulMuridbook used the following formula:

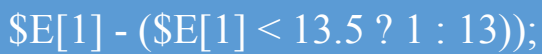

Based on the formula above, attainingC.E month which was generated ijtima' required certain $\mathrm{E}$ score. If E score was smaller than 13.5, C.E month would be $\mathrm{E}-1$. Then, if $\mathrm{E}$ score was bigger than 13.5, C.E month would be E-13.

As the result, it could be assumed that PHP program code of IrsyadulMuridbook was more comprehensive than IrsyadulMuridbook's explanation. In Astronomical Algorithms of Jean Meeus, C.E month which generated Ijtima' should employed the rationality by considering $\mathrm{E}$ score.

2. JD Calculation of GhurubTaqribi(Sunset Calculation Approach)

In IrsyadulMuridbook, after recognizing the ijtima', the next step was calculating the sun ephemeris data on ghurubtaqribi time at 6 p.m local time. The calculation of sun ephemeris data on ghurubtaqribi time required JD data of ghurubtaqribi time, 18 hours behind the local time. IrsyadulMurid ${ }^{19}$ book used the followingformula:

$$
\begin{aligned}
\mathrm{JD}= & \operatorname{Int}(365.25 \times(\mathrm{Y}+4716))+\operatorname{Int} \\
& (30.6001 \times(\mathrm{M}+1))+\mathrm{Tg} 1+\mathrm{B} \\
& +(18-\mathrm{TZ}): 24-1524.5
\end{aligned}
$$

However, PHP program code of IryadulMurid employed the following formula:

\section{$\$ J D 1=\operatorname{intval}(365.25 *(\$ t h n I+$ \\ $4716))+\operatorname{intval}(30.6001 *$ \\ $(\$ b \operatorname{lnI}+1))+\$ T G L[1]+\$ B 2$}

In sum, the JD calculation of gburubtaqribion PHP program code ofIrsyadulMuridused 0 GMT. Likewise, IrsyadulMuridbook stated different justification, 18 hours behind local time. Therefore, there was different calculation result between sun ephemeris data and ghurubtaqribi time. Comparing with other justifications of ghurubtaqribi time, FalakPractice, Hisab Method-Rukyat Practice by Ahmad Izzuddin and Solution and Falakin Theories and Practice by MuhyidinKhazin, sun ephemeris of gburubtaqribi data used was 18 hours behind the local time. Hence, 18 hours behind the local time was the closest to gburub.

3. The Calculation of GhurubTaqribi On ghurubtaqribi calculation process series, the difference between IrsyadulMuridbook and PHP program code of IrsyadulMuridwas not only on JD calculation but also on ghurubtaqribi time calculation. In IrsyadulMuridbook, sun's angle calculation at ghurubtaqribi used the following formula ${ }^{20}$ :

\footnotetext{
${ }^{19}$ Ahmad Ghazali Muhammad Fathullah, Irsyadul Murid, (Lanbulan :Lafal, 2005) p. 137.
}

\footnotetext{
${ }^{20}$ Ahmad Ghazali Muhammad Fathullah, Irsyadul Murid, (Lanbulan :Lafal, 2005) p. 138.
} 
146 | Iqnaul Umam A, Irsyaduk Murid Hisab, hlm.141-150

$$
\begin{aligned}
& \operatorname{Dip}=(1.76 / 60) \times \sqrt{ } \mathrm{TT}(0) \\
& \mathrm{h}=-\left(\mathrm{s} . \mathrm{d}+34.5^{\prime}+\operatorname{Dip}\right) \\
& \mathrm{t}=\operatorname{Cos}^{-1}(-\tan \phi \times \tan \delta \\
& +\operatorname{Sin} \mathrm{h} / \operatorname{Cos} \phi / \operatorname{Cos} \delta) \\
& \text { Ghurub }=\mathrm{t} / 15+(12-\mathrm{e})
\end{aligned}
$$

On the other side, PHP program code of IrsyadulMuridused the following formula:

$$
\begin{aligned}
& \$ s d=0.267 /(1-0.017 * f \cos (\$ m)) \\
& \$ \operatorname{Dip}=(1.76 / 60) * \operatorname{sqrt}(\$ T T) \\
& \$ \mathrm{~h}=-(\$ s d+34.5 / 60+\$ D i p) \\
& \$ t=f a c o s(-f t a n(\$ L T) * f t a n(\$ M a i l A)+f \sin (\$ h) / f \cos (\$ L T) / f \cos (\$ M a i l A)) \\
& \$ \text { Ghurub }=\$ \mathrm{t} / 15+(12-\$ \mathrm{e})-\$ \mathrm{TZ} \\
& \$ B Q u t r=f a \sin (f \sin (\$ L T) * f \sin (\$ M a i l A)) \\
& \$ A M u t l q=f a s i n(f \cos (\$ L T) * f \cos (\$ M a i l A)) \\
& \$ \text { Ghurub }=\text { facos }(-(\text { fsin }(0.808)+\text { fsin }(\$ B Q u t r) / \text { fsin( } \$ \text { AMutlq }))) / 15+ \\
& \text { getSelisihWibWis(\$BLN[1], \$TGL[1], \$BT, \$TZ) + } 12 \text { - \$TZ; }
\end{aligned}
$$

Based on the formula above, there were two formulas which were used in the following ghurubtagribiformula:

$$
\begin{aligned}
& \$ t=f a c o s(-f \tan (\$ L T) * f t a n(\$ M a i l A)+f \sin (\$ h) / f \cos (\$ L T) / f \cos (\$ M a i l A)) \\
& \$ \text { Ghurub }=\$ \mathrm{t} / 15+(12-\$ \mathrm{e})-\$ \mathrm{TZ}
\end{aligned}
$$

$$
\$ B Q u t r=f a s i n(f \sin (\$ L T) * f \sin (\$ M a i l A))
$$

Also,

$\$ A M u t l q=f a s i n(f \cos (\$ L T) * f \cos (\$ M a i l A))$ 
$\$$ Ghurub $=$ facos $(-($ f sin $(0.808)+$ fsin $(\$ B Q u t r) /$ fsin $(\$ A M u t l q))) / 15+$ getSelisihWibWis(\$BLN[1], \$TGL[1], \$BT, \$TZ) + 12 - \$TZ;

On the first formula, the calculation between PHP program code of ghurubtagribi andIrsyadulMuridbook were alike. Ghurub caused by time angle, was calculated by the high angle data of the sun and used Dip correction (ufuk low angle). The calculation result of ghurubtaqribi on those program code was saved on $\$$ ghurub variable. However, saved data on $\$$ ghurub variable was replaced by new calculation result data $\mathrm{facos}((\mathrm{f} \sin (0.808)+\mathrm{f} \sin (\$ \mathrm{BQutr}) / \mathrm{fsin}(\$ \mathrm{AMu}$

tlq)))/15+getSelisihWibWis(\$BLN[1],

\$TGL[1], \$BT, \$TZ) + 12 - \$TZ

Then, it would be translated as the following formula:

$\operatorname{Cos} \mathrm{t}=-\left(\sin (0.808)+\sin \left(\$ B u^{\prime}\right.\right.$ dulQutr $) /$

$\sin ($ AshlMutlaq)))

Ghuruh $=\mathrm{t} / 15+(\mathrm{T} 7,-\mathrm{RT} / 15)+12-\mathrm{T} 7$.
As \$ghurub variable was defined twice, saved score on \#ghurubvariable was the second result calculation which $\cos t$ did not use h score (the high sun angle on ghurub) by considering Dip and replacing 0.808 Constanta or 0॰48'28, 8 ". Therefore, it could be concluded

\section{Analysis of the Hisab Accuracy Level of the Beginning Islamic lunar month Based on \\ IrsyadulMuridBook in Ahmad TholhahMa'ruf Digital Falak Web- Based}

1. The Accuracy Level pf Digital Falak Web-Based Based on IrsyadulMuridBook that PHP program code of ghurubtaqrbi calculation did not utilized Dip correction (ufuklow angle). In addition, there was difference inIrsyadulMuridbook justifications which employed Dip correction in calculating ghurubtagribi

To examine the hisab accuracy level of the beginning Islamic lunar month based on IrsydaulMurid book in Ahmad TholhahMa'ruf digital falak web-based, the researcher had conducted calculation starting on Ramadhan 1436 Hijria based on digital falak web-based and IrsyadulMuridbook

Table 4.3 Ijtima' the Beginning Ramadhan 1436 Hijria Based on Digital Falak Web-Based and IrsyadulMuridBook 


\begin{tabular}{|c|c|}
\hline \multicolumn{2}{|c|}{ Hisab Awal Bullan Ramadan Tahun $1436 \mathrm{H}$. } \\
\hline Awal bulan & : Kamis Pon, 18 Jun 2015 \\
\hline Ijtima Tejadi Pada & : Malam Rabu Legi, 16 Jun 2015 \\
\hline Jam Ijtima & : 08:47 WIS | 21:09 W.Setempat. \\
\hline Arah Hilal & : Di Utara Matahari \\
\hline Posisi Hilal & ; Miring ke Utara \\
\hline Azimut Matahari & : $23^{\circ} 24^{\prime}$ sebelah utara titik barat \\
\hline Azimut Bulan & : $18^{\circ} 19^{\prime}$ sebelah utara titik barat \\
\hline Tinggi Hilal [Malam Rabu] & $:-02056$ \\
\hline Lama Hilal & $:-00: 07$ \\
\hline Cahaya Hilal & $: 0.002$ Usbu \\
\hline Matahari Terbenam & :05:45 WIS | 17:24 W.Setempat \\
\hline Markaz & : semarang $\left(-07^{\circ} 00^{\prime} \mid 110^{\circ} 26^{\prime}\right)$ \\
\hline
\end{tabular}

\begin{tabular}{|c|c|}
\hline \multicolumn{2}{|c|}{ KETERANGAN } \\
\hline \multicolumn{2}{|c|}{$\begin{array}{l}\text { Jitimak akhir bulan SYABAN } 1438 \text { terjadi } \\
\text { pada hari Selasa Legi Tol. } 18 \text { Juni zons } \\
\text { Jam } 21: 8: 33 \text { LT }\end{array}$} \\
\hline \multicolumn{2}{|c|}{$\begin{array}{l}\text { Tinggi Hilal Mar' pada hari Selasa Legi. } 16 \\
\text { Juni 2015 masih dibawah ufuq }\end{array}$} \\
\hline \multicolumn{2}{|c|}{$\begin{array}{c}\text { Data Obeerwasi Hilal sa at Maahrib } 17: 30: 68.7 \\
\text { Hari Selasa Legi, to Juni } 2015\end{array}$} \\
\hline Uimur Hilal & $-3:-37:-38, J \mathrm{am}$ \\
\hline Tinggi Hilal Haqiai & $-1^{\prime}=\mathrm{Eg}^{\prime} \quad 0,8 \mathrm{E}^{\prime}$ \\
\hline Tinggi Hilal Mar'I & Dibawah ufug \\
\hline Lama Hilal & $0: 0: 0 \mathrm{Jam}$ \\
\hline Aximit Halal & $2 B B=1 B=53, B^{\prime}$ \\
\hline Azimut Hilal dari barat & $18=18^{\prime} 53.8^{\prime \prime}>U$ \\
\hline Aximut Matahari & $253=24^{\circ} 14,4^{\prime \prime}$ \\
\hline Ascimut Mithr dari barat & $23=24^{-14}+4^{\prime}=U$ \\
\hline Jarak Hilal - Matahari & $5^{\prime \prime} 5^{\prime} 20,63^{\prime \prime}$ \\
\hline Fosisi Hilal & Selatan Matahari \\
\hline Keadaan Hilal & Dibawah ufuq \\
\hline Nuruil Hilal jari & Nol jari \\
\hline Nurul Halal $\%$ & Nod persen \\
\hline Ghurub Hilal Haqiai & $17: 20: 51.8$ \\
\hline Terbit Hilal Haqiqi & $5: 14: 53,3$ \\
\hline Terbit Matahari & $5: 48: 48.2$ \\
\hline Jar.ak Bumi - Bulan & $3=83558,39245 \mathrm{~km}$ \\
\hline Jarak Bumi - Matahari| & $1519 \mathrm{ag} 3.87 .22 \mathrm{~km}$ \\
\hline
\end{tabular}

Source: https://www.digitalfalak.com/ andIrsyadulMuridbook

On digital falak web-based layout, the display day on ijtima' line stated Tuesday night. However, Pasaran(fiveday week)day should be stated on the next day, Pabing. Based on the researcher analysis, there was vague in constructing PHP program language on digital falak web-based. On month and sun azimuth row, digital falak webbased did not calculate from west instead of north in clockwise direction as azimuth justification. In addition, the data presentation basis did not employed second data yet rounded off to minute basis. As the result, both data would generate similar result. Thehigh level of hilal was shown as (-) sign even though it was under the ufuk. Furthermore, the calculation of markaz. (altitude) was quite distinct from the IrsyadulMuridbook which was $110^{\circ}$ 24'while digital falak web-based markaz was $110^{\circ} 26^{\prime}$. As the result, there was quite distinct, though trivial, calculation result data.

It could be assumed that the date modification on bisab row did not affect the result of ijtima' of the beginning Ramadhan 1436 Hijriain digital falakweb-based. Consequently, users would face difficulty in seeking the high level of bilal of the beginning date for every Islamic lunar month. Then, there was one minute deviation on Ramadhan 1436 Hijria. There was Mo (thul al-Qomar) score anomaly which was negative instead of positive. If there was mistake Thul alQomar(month longitude) score, Matholi' mustaqimah li qomar(month right ascension) score would generate error result. Matholimustaqimaband thul score had to be in similar quadrant. If matholimustaqimabwas incorrect, it would affect zawiyablilqomar (the angle time of month). Zaqiyahzamanlilqomarformula by K.H Ahmad Ghozali M. Fathullohemployed zamannajmi (sidereal time) equation minus motholi' mustaqimablilqomar score, plus thul al balaqsyarqi. If zawiyahzamanlilqomarscore was incorrect, it could be assume that bilalirtifa' would be incorrect. In addition, there was several mistakes in digital falak web-based which some months was inappropriate to pasaran onRamadhan 1436 Hijria. In this case, there was algorithm mistake in bisaburfi'conversionin determining pasaranday. Auto detection of coordinate point in digital falak webbased wasdifferent to IrsyadulMuridbook. Due to advance and 
sophisticated digital falak web-based, the synchronization between latitude and longitude and Google result would affect in minutes. Month period in digital falak web-based was not stated, so it should be looked by the users themselves andobscured them. Moreover, rukyahdata was not available because presented hisab date was before rukyah date/ the $29^{\text {th }}$ of month.

2. Digital falak web-based application has its strengths and weaknesses. The following list was digital falak webbased strengths:

a. It was user friendly for average people that they did not need to calculate bisab of the beginning Islamic lunar month based on IrsyadulMuridbook for hours. However, users should select the calculation according to their need. It could be either the final result of bisabijtima' or comprehensive result of hisabijtima'.

b. It was user friendly that could be accessed anytime and anywhere without installing it first.

c. Digital falak web-based could be operated by any operation systems such as Linux or Windows aslong as having web browser and internet connection.

d. Digital falak web-based use .com domain whose stood for commercial. This domain extension was intended for commercial for instances personal or corporate blog/website. It was well-known, international-scale, extension domain which captivate web visitors. Auto detection of location used had been synchronized by Google in order to get high accuracy level of latitude and longitude based on particular city which users inserted.

Besides its strength, digital falak webbased had several weaknesses such as:

a. It required steady internet connection so users could access it. b. On date column, it did not work well and users could not inserted based on their needs.

\section{CONCLUSSION}

Based on analysis and discussion above, the researcher could concluded as follows:

1. There was distinct algorithm and formula used between digital falak web-based and IrsyadulMuridbook. They were Gregorian month logic of Ijtima' occurrence, JD calculation of ghurubtaqribi and calculation of ghurubtaqribi. Due to this differences, it would affect the result of hisab of the beginning Islamic lunar month.

2. Data rukyah was unavailable because it presented rukyah date was before rukyah date/ the 29th of month. This design flaw caused imprecise of accuracy level in digital falak webbased application.

\section{SUGGESTIONS}

The urge of upgraded version of digital falak web-based would be necessarily needed in order to maintain the accuracy level as in IrsyadulMuridbook. It was undeniable that IrsyadulMuridbook was including contemporary book as Ephemeris and Jean Meeus. Therefore, there was no difference use in digital falak webbased application. In addition, it was necessary to develop digital falak web-based based on several falak books so it could enriching falak science. Development of falak in determining the beginning Islamic lunar month should be fostered. Hence Ministry of religion should appreciate falak experts'works. 


\section{REFERENCES}

Abd. Salam, Nawawi, 2006, IlmuFalak : Cara Praktis Menghitung Waktu Shalat Arah Kiblat dan Awal Bulan .Sidoarjo : Aqaba.

Ahmad Ghazali Muhammad Fathullah, 2005, IrsyadulMurid,Lanbulan :Lafal.

BethaSidikdanHusniIskandarPohan , 2014, Pemrograman WEB denganHTML RevisiKelima, Bandung : Informatika.

Imam Suprayogodan'Tobroni, , 2001,Metodologi PenelitianSosial-Agama, Bandung: PT RemajaRosdaKarya.

JusufSoewadji, 2012, PengantarMetodologiPenelitian, Jakarta: MitraWacana Media.

KitriSulastri, 2011, StudiAnalisisHisab AwalBulanKamariahDalam KitabIrsyadulMurid, Skripsi:S1FakultasSyari'ah IAIN Walisosngo Semarang.

M.Suyanto,2003,MultimediaAlatUntuk:Meningkat kanKeunggulanBersaing, Yogyakarta : Andi.

MuhyidinKhazin, 2005, KamusImuFalak, Jogjakarta: BuanaPustaka.

SoerjonoSokantodan Sri Mamudji, 1986, PenelitianHukumNormatifS uatuTinjauanSingk at, Jakarta: Rajawali.
Sriyatin Shadiq,1995,

PerkembanganHisabRukyahdanPenetapan Awal BulanQomariyabdalamMenujuKesatuanHari Raya, Surabaya : BinaIlmu.

Sugiyono, 2008, MetodePenelitianPendidikanPendekatanKuantit atif, KualitatifdanR \& D, Bandung :Alfabeta.

SuharsimiArikunto, 2010, ProsedurPenelitian: SuatuPendekatanPraktik, Jakarta: RinekaCipta.

Yuhefizer, S. Kom, dkk, Cara MudabMembangun Website InteraktifMenggunakan Content Management System Joomla (CMS) EdisiRevisi, (Jakarta: PT. Elex Media Komputindo.

\section{Interview:}

Interview result with Ahmad Tholhah bin Ma"ruf on Friday, 07 April 2017 in MasjidWarungdowoTimur, Warungdowo, Pohjentrek, Pasuruan Province, East java at 09.00 .

\section{Website :}

Tekno.kompas.com/amp/read/2016/10/24/1 5064727/2016.pengguna.internet.di.indonesia.c apai.132.juta.accessed on Thursday 9 February 2017 at 13.00 . 